\title{
Optimization of Chalcopyrite Galvanic Leaching in the Presence of Pyrite and Silver as Catalysts by using Response Surface Methodology (RSM)
}

Rudarsko-geološko-naftni zbornik

(The Mining-Geology-Petroleum Engineering Bulletin) UDC: 622.7

DOI: 10.17794/rgn.2021.1.4

Original scientific paper

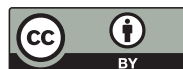

\author{
Sajjad Chehreghani'; Mojtaba Yari²; Amir Zeynali'; Behzad Nemati Akhgar'; \\ Hojjat Hosseinzadeh Gharehgheshlagh'; Mahsa Pishravian ${ }^{2}$ \\ ${ }^{1}$ Department of Mining Engineering, Urmia University, Urmia, Iran \\ ${ }^{2}$ Department of Mining Engineering, Faculty of Engineering, Malayer University, Malayer, Iran \\ ${ }^{3}$ Mining Engineering Department, Faculty of Environment, Urmia University of Technology (UUT), Urmia, West Azerbaijan, Iran. \\ ORCID (https://orcid.org/0000-0002-7763-9596).
}

\begin{abstract}
In this research, dissolution of chalcopyrite concentrate is modelled and optimized using Response Surface Methodology (RSM). Also, effective parameters in the leaching process such as the amount of pyrite, silver ions, redox potential and initial concentration of acid are comprehensively studied. Central Composite Design (CCD) methodology is chosen as the design matrix to predict the optimum level of the parameters. In the next step, it will be proven that in the presence of silver ions, pyrite effectiveness is improved and also the chalcopyrite dissolution rate is increased considerably. Using the result of quadratic programming, a rotation speed of $1000 \mathrm{rpm}$, a pyrite/chalcopyrite mass ratio of 3:1, the amount of $150 \mathrm{ppm}$ silver ion, a solution potential set point of $470 \mathrm{mV}$, at $800^{\circ} \mathrm{C}$ and $25 \mathrm{~g} / \mathrm{L}$ initial acid concentration are the optimal level of the selected parameters wherein the maximum copper extraction with more than $95 \%$ in less than 10 hours can be accessible.
\end{abstract}

Keywords:

Chalcopyrite; Dissolution; Galvanic effect; Response Surface Methodology

\section{Introduction}

Presently, 80-85 percent of copper is produced by the flotation of copper ores before a pyrometallurgical process of smelting and converting. In recent years, regarding hydrometallurgical processing advantages, copper production through hydrometallurgy processes is a matter of interest (Harmer et al., 2006). Hydrometallurgical processes, in comparison to the pyrometallurgy method, may be preferred due to its lower costs, economical approaches and its environmentally friendly impacts such as the reduced emission of $\mathrm{SO}_{2}$ into the atmosphere. The subject mentioned above will be more evident especially in the case of low-grade copper ores (Córdoba et al., 2008). Hydrometallurgical processes can be classified according to solvents used such as sulfur, chloride and ammonia. As previous attempts have proven, these processes were not very welcome in the copper industry due to the low rate of chalcopyrite leaching and low copper recovery (Hiroyoshi et al., 2002). For this reason, a comprehensive investigation for the understanding of kinetics and the mechanism of chalcopyrite leaching can be considered as essential issues to be used in the industry. Previously, extensive studies have been conducted on chalcopyrite leaching by sulfu-

Corresponding author: Sajjad Chehreghani

s.chehreghani@urmia.ac.ir ric acid, hydrochloric acid and other leaching agents (Córdoba et al., 2009b; Hackl et al., 1995; Stott et al., 2000; Viramontes-Gamboa et al., 2010). Among these processes, ferric sulfate leaching of chalcopyrite has many advantages; simplicity of leaching reactions, proper leaching progress, low operating and capital cost, ease of copper recovery with solvent extraction and electrowinning (Nazari et al., 2011). However, the formation of a passive layer during chalcopyrite leaching on the surface of a mineral can diminish the advantages by preventing reactant transportation on the chalcopyrite interface with the leach liquor. The passive layer is mainly responsible for ineffective copper extraction, an incomplete leaching process and slow kinetics of chalcopyrite leaching (Arce and González, 2002). The nature of the passive layers and its characterization have been considered as a challenging issue, discussed in former investigations (Li et al., 2010). Different theories about the nature of the layer have been developed based on different methods. Elemental sulfur (Antonijević et al., 1994; Xian et al., 2012), disulfide (Klauber et al., 2001; Linge, 1977; Yin et al., 1995), polysulfide (Parker et al., 1981) and ferrous hydroxyl-oxide (Buckley and Woods, 1984) are the proposed materials that probably formed the impermeable and resistant layer.

Nazeri et al., (2011) proved that the addition of pyrite in order to facilitate an electrochemical interaction be- 


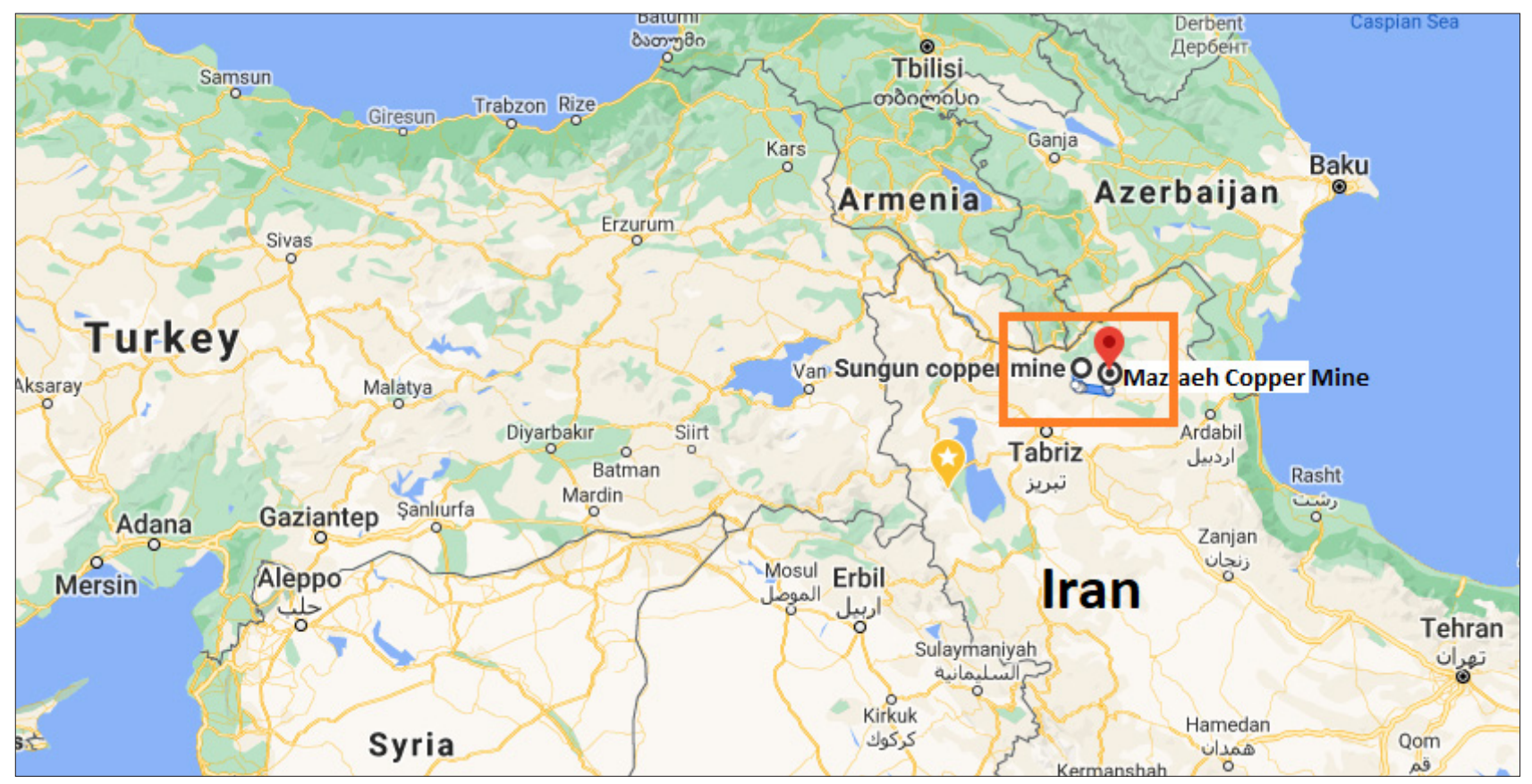

Figure 1: Geographical location of Sungun copper plant and Mazraeh copper mines

Table 1. Chemical analysis of chalcopyrite concentrates and pyrite samples

\begin{tabular}{|l|c|c|c|c|c|c|c|}
\hline Component & $\mathbf{C u} \%$ & $\mathbf{F e} \%$ & $\mathbf{S} \%$ & $\mathbf{S i O}_{\mathbf{2}} \%$ & $\mathbf{A l}_{\mathbf{2}} \mathbf{O}_{\mathbf{3}} \%$ & $\mathbf{C a O} \%$ & $\mathbf{M o} \%$ \\
\hline Chalcopyrite & 28.2 & 32.46 & 28.27 & 4.45 & 2.15 & 0.75 & - \\
\hline Pyrite & 4.46 & 45.96 & 32.07 & 2.11 & 1.48 & 0.44 & 0.004 \\
\hline
\end{tabular}

tween pyrite and chalcopyrite is the most effective method for accelerating chalcopyrite leaching (Nazari et al., 2011). Nowadays, the mentioned process is known as galvanox which has more benefits than other extraction processes. Pyrite and chalcopyrite, are both naturally associated with each other and therefore the co-treatment of these minerals can be advantageous from an economic point of view (Salehi et al., 2016). The galvanox process has been carried out under atmospheric pressure without costly requirements such as expensive leaching tanks. Additionally, due to the high content of sulfur $(>95 \%)$ obtained during the leaching process under the temperature conditions used, oxygen consumption and sulfuric acid production have been reduced. The operational temperature of the process under sulfur's melting point lead to the elimination of the surface activator agent and consequently, there was no need for more grinding in the method (Dixon et al., 2007). In the presence of pyrite, ferric ions were reproduced in the leach solution, keeping the solution potential in the mineral's active region (Koleini et al., 2011; Koleini et al., 2010).

Besides using pyrite, the silver ions also can be applied for chalcopyrite leaching wherein silver ions combine with sulfur on a chalcopyrite surface acting as an insulator layer by silver sulfide formation during leaching reactions (Yuehua et al., 2002). With the formation of the insulator layer, the remaining surface of chalcopyrite can contribute in the leaching reaction and conse- quently pyrite can release copper in the modified conditions (Córdoba et al., 2009a, 2009b). Various experiments and analyses have been conducted to understand the effect of silver on chalcopyrite leaching in the galvanox process while there have not been enough studies carried out to improve the galvanox process with the addition of silver. Therefore, the present research aims to investigate the effects of various parameters on copper extraction during the galvanox process. For that, the dissolution of chalcopyrite concentrate of the Sungun copper plant was examined in various leaching conditions by changing the parameters of the amount of pyrite and silver ion added, the redox potential and the initial concentration of the acid.

\section{Materials and methods}

A typical chalcopyrite copper sulfide concentrate $\left(\mathrm{CuFeS}_{2}\right)$ and pyrite with relatively high purity are prepared from the Sungun copper plant and the Mazraeh copper mine located in Ahar (East Azerbaijan, Iran), respectively, see Figure 1. A chemical analysis of chalcopyrite concentrate and pyrite samples is presented in Table 1.

The leaching experiments were performed in a stirred tank reactor with a pulp density of $10 \%$. Most of the chalcopyrite and pyrite have particle sizes under $37 \mu \mathrm{m}$. Previous investigations revealed that the leaching reac- 
tion rate of chalcopyrite concentrate was doubled with every $10^{\circ} \mathrm{C}$ increase of temperature (Berry et al., 1978). Although temperature is an important parameter in chalcopyrite dissolution, the influence of temperature on chalcopyrite dissolution has not been studied, especially in sulfate media with a ferric ion (Dutrizac, 1981). The required temperature to perform leaching tests was cited as $80^{\circ} \mathrm{C}$ (Córdoba et al., 2008; Dreisinger and Abed, 2002) by using a water bath and an electrical heater.

Table 2. Leaching parameters and their levels used in the in RSM design

\begin{tabular}{|l|l|c|c|c|c|c|}
\hline \multirow{2}{*}{$\begin{array}{l}\text { Independent } \\
\text { variable }\end{array}$} & \multirow{2}{*}{ Symbol } & \multicolumn{5}{|c|}{ levels } \\
\cline { 3 - 7 } & & $-\boldsymbol{\beta}$ & $-\mathbf{1}$ & $\mathbf{0}$ & $+\mathbf{1}$ & $+\boldsymbol{\beta}$ \\
\hline $\begin{array}{l}\text { Pyrite's ratio to } \\
\text { chalcopyrite }\end{array}$ & $\mathrm{A}$ & 1 & 2 & 3 & 4 & 5 \\
\hline Silver ion (ppm) & $\mathrm{B}$ & 50 & 100 & 150 & 200 & 250 \\
\hline Eh vs Ag/AgCl & $\mathrm{C}$ & 410 & 440 & 470 & 500 & 530 \\
\hline $\begin{array}{l}\text { Acid concentrate } \\
\text { (g/L) }\end{array}$ & $\mathrm{D}$ & 5 & 15 & 25 & 35 & 45 \\
\hline
\end{tabular}

Various studies have uncovered that stirring speed does not have a significant influence on the dissolution of chalcopyrite (Antonijević and Bogdanović, 2004) and thus the reaction rate is not controlled by mass transfer. Nevertheless, stirring is necessary to keep pulp suspended and for this reason, a beater stirring speed of 1000 rpm was used in all experiments. Sulfuric acid with a purity of approximately $98 \%$ was used for increasing the solution acidity. After setting the $\mathrm{pH}$ levels, the laboratory hydrogen peroxide solution was applied to control the redox potential at the desired levels. In all experiments, $5 \mathrm{~g}$ of chalcopyrite, and the appropriate amount of pyrite and silver ion were added to the leaching reactor. Although, other parameters could be effective in chalcopyrite leaching, the parameters of pyrite to chalcopyrite ratio, silver ion amount, acid concentration and solution redox potential, were selected for the experimental design step in our research. The redox potential measurement was conducted by using working electrodes of a carbon paste electrode and a reference electrode $\mathrm{Ag} /$ $\mathrm{AgCl}$ and a platinum counter electrode. The electrodes

Table 3. Parameter levels used for each of the 30 test runs and their results

\begin{tabular}{|c|c|c|c|c|c|c|c|}
\hline Std & Run & Block & $\mathrm{Py} / \mathrm{Cp}$ & $\operatorname{Ag}(p p m)$ & Eh (mV Ag/AgCl) & Acid (g/L) & $\mathbf{R}(\%)$ \\
\hline 18 & 1 & Block 1 & 3 & 150 & 470 & 25 & 99 \\
\hline 12 & 2 & Block 1 & 4 & 200 & 440 & 35 & 83 \\
\hline 9 & 3 & Block 1 & 2 & 100 & 440 & 35 & 74.6 \\
\hline 5 & 4 & Block 1 & 2 & 100 & 500 & 15 & 75 \\
\hline 14 & 5 & Block 1 & 4 & 100 & 500 & 35 & 79.9 \\
\hline 17 & 6 & Block 1 & 3 & 150 & 470 & 25 & 92.7 \\
\hline 15 & 7 & Block 1 & 2 & 200 & 500 & 35 & 75.2 \\
\hline 3 & 8 & Block 1 & 2 & 200 & 440 & 15 & 81.6 \\
\hline 8 & 9 & Block 1 & 4 & 200 & 500 & 15 & 85.9 \\
\hline 2 & 10 & Block 1 & 4 & 100 & 440 & 15 & 81.7 \\
\hline 19 & 11 & Block 2 & 3 & 150 & 470 & 25 & 95 \\
\hline 20 & 12 & Block 2 & 3 & 150 & 470 & 25 & 97.8 \\
\hline 7 & 13 & Block 2 & 2 & 200 & 500 & 15 & 79 \\
\hline 4 & 14 & Block 2 & 4 & 200 & 440 & 15 & 87.7 \\
\hline 11 & 15 & Block 2 & 2 & 200 & 440 & 35 & 82.4 \\
\hline 6 & 16 & Block 2 & 4 & 100 & 500 & 15 & 84 \\
\hline 16 & 17 & Block 2 & 4 & 200 & 500 & 35 & 82 \\
\hline 10 & 18 & Block 2 & 4 & 100 & 440 & 35 & 81.3 \\
\hline 13 & 19 & Block 2 & 2 & 100 & 500 & 35 & 70.1 \\
\hline 1 & 20 & Block 2 & 2 & 100 & 440 & 15 & 76.5 \\
\hline 27 & 21 & Block 3 & 3 & 150 & 470 & 5 & 74.7 \\
\hline 26 & 22 & Block 3 & 3 & 150 & 530 & 25 & 59.3 \\
\hline 24 & 23 & Block 3 & 3 & 250 & 470 & 25 & 95.3 \\
\hline 30 & 24 & Block 3 & 3 & 150 & 470 & 25 & 97 \\
\hline 22 & 25 & Block 3 & 5 & 150 & 470 & 25 & 99 \\
\hline 28 & 26 & Block 3 & 3 & 150 & 470 & 45 & 73.8 \\
\hline 23 & 27 & Block 3 & 3 & 50 & 470 & 25 & 82.2 \\
\hline 25 & 28 & Block 3 & 3 & 150 & 410 & 25 & 65.7 \\
\hline 29 & 29 & Block 3 & 3 & 150 & 470 & 25 & 93.8 \\
\hline 21 & 30 & Block 3 & 1 & 150 & 470 & 25 & 79 \\
\hline
\end{tabular}


Table 4. The results of the ANOVA analysis for the response model and p-values of variables

\begin{tabular}{|l|l|l|l|l|l|}
\hline Source & Sum of Squares & df & Mean Square & F Value & p-value Prob $>$ F \\
\hline Block & 12.842 & 2 & 6.421 & & \\
\hline Model & 2844.631 & 10 & 284.463 & 64.750 & $<0.0001$ \\
\hline A-Py/Cp & 200 & 1 & 200 & 45.524 & $<0.0001$ \\
\hline B-AgCl & 149.500 & 1 & 149.500 & 34.029 & $<0.0001$ \\
\hline C-Eh & 38.760 & 1 & 38.760 & 8.822 & 0.0086 \\
\hline D-Acid & 25.420 & 1 & 25.420 & 5.786 & 0.0278 \\
\hline AB & 6.630 & 1 & 6.630 & 1.509 & 0.2360 \\
\hline$A^{\wedge} 2$ & 61.115 & 1 & 61.115 & 13.911 & 0.0017 \\
\hline$B^{\wedge} 2$ & 66.340 & 1 & 66.340 & 15.100 & 0.0012 \\
\hline$C^{\wedge} 2$ & 1807.465 & 1 & 1807.465 & 411.423 & $<0.0001$ \\
\hline$D^{\wedge} 2$ & 736.033 & 1 & 736.033 & 167.539 & $<0.0001$ \\
\hline AB`2 & 17.400 & 1 & 17.400 & 3.960 & 0.0629 \\
\hline Residual & 74.684 & 17 & 4.393 & & \\
\hline Lack of Fit & 45.799 & 14 & 3.271 & 0.339 & 0.9304 \\
\hline Pure Error & 28.885 & 3 & 9.628 & & \\
\hline Cor Total & 2932.158 & 29 & & & \\
\hline
\end{tabular}

were connected to a voltmeter device to measure the solution redox potential. Among several methods, Response Surface Methodology (RSM) and the Central Composite Design (CCD) approach were preferred for designing a series of experiments through design expert software Dx7.

At determined time intervals, samples were taken from the reactor and the leach residues were separated after 3 minutes of centrifuging at $5000 \mathrm{rpm}$. To keep the liquid volume fixed during the leaching process, the samples were returned to the reactor after centrifugation and also, the liquid volume was set daily with the addition of distilled water. Then, the copper concentration of the samples was measured by using an Atomic Absorption Spectroscopy instrument of Varian 220, where the Varian $220 \mathrm{G}$ is for the graphite-furnace atomic absorption analysis of solutions.

\section{Experimental design}

To save time and in order to reduce costs, a CCD design was applied to obtain reliable information about chalcopyrite galvanic leaching in the presence of pyrite and silver. Regarding the relationship between variables in the experimental design method used in the present study, leaching parameters and their levels are reported in Table 2. Furthermore, parameter levels used for all of the runs and the achieved results are summarized in Table 3.

\section{Results and discussion}

Applying the related software, the influences of the used model terms are estimated using the obtained responses. The statistical calculations include the F-values, lack of fit, and coefficients of determination values $\left(\mathrm{R}^{2}\right)$. The $\mathrm{R}^{2}$ values are employed for process modelling and then, a proper quadratic model is sensibly selected. The model major terms are calculated by some insignificant variables and after these, interactions of those with the lowest F-values are overlooked. Therefore, the ANOVA test is used as a powerful statistical tool (see Table 4).

A sum of squares due to lack of fit, or more tersely a lack-of-fit is one of the components of a partition of the sum of squares of residuals in an analysis of variance (ANOVA), used in the numerator in an F-test of the null hypothesis that says that a proposed model fits well. Therefore, the lack-of-fit F-test for model validity checking is used as the test can indicate the residual and the pure errors. It is worth mentioning that lack-of-fit is unsuitable and small values of $\mathrm{F}$ and a probability of more than 0.1 are preferred. The models with small lack-of-fit values are not acceptable for the prediction of the response obtained (Ferreira et al., 2007). Regarding the results presented in Table 4, the lack-of-fit for a selected model is 45.799 with a probability more than 0.1 . In addition, the model can be considered notably significant in accordance with a very low obtained probability value $(<0.0001)$. Besides a very high determination coefficient $\left(\mathrm{R}^{2}=0.9744\right)$, a very low value obtained for the coefficient of variation (2.53) estimated for the model proved that a predicted response through the model can be reliable and precise as cited before (Liu and Chiou, 2005; Zinatizadeh et al., 2006). The adequate precision of 28.296 measures a proper signal to noise ratio value wherein a ratio of more than 4 is sufficiently applicable (Körbahti and Rauf, 2008). As well, the predicted sum of square (PRESS) is a tool for the evaluation of a particular model to assess the fitting quality of points involved in the design step (Isar et al., 2006). Furthermore, Table 4 presents the acquired amounts of p-value for each variable in the polynomial model of bonded 
particles. The values of "Prob. > F" which are less than 0.05 are correlated with superior model terms while values greater than 0.1 indicate inferior model terms which could be ignored.

\subsection{Discussion on the influence of parameters on recovery}

\subsubsection{Effects of acid concentration}

Figure 2 depicts the effect of primitive acid concentration on copper dissolution. As can be seen, the initial acid concentration does not have much of an effect on recovery, but a small decrease in copper recovery in high acid concentrations in the presence of pyrite and silver can be attributed to an increase in pyrite dissolution and a loss of silver in acidic solutions.

Acid concentrations directly affecting the kinetic process were related to the ability of controlling the leaching process and economic issues in industry (Dreisinger and Abed, 2002). There is no doubt that low $\mathrm{pH}$ minimizes the hydrolysis of $\mathrm{Fe}^{3+}$ and its precipitation. It is

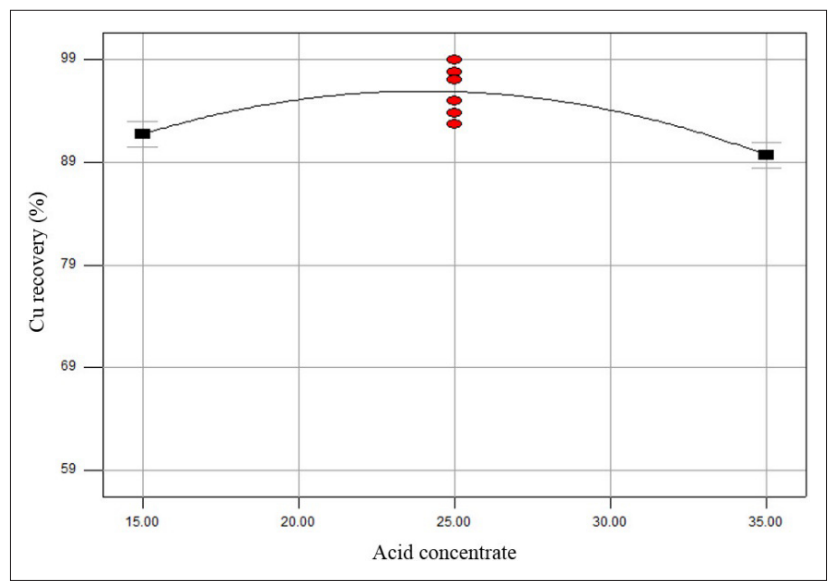

Figure 2: The effect of acid concentration on the dissolution of copper seen in chalcopyrite leaching that any increase in acid concentration promotes copper dissolution and the best amount of acid concentration in the leaching process ranges between 0.1 and $1 \mathrm{M}$ (Aydogan et al., 2006). At lower concentrations $(\mathrm{c}<0.5 \mathrm{M})$ and higher concentrations $(\mathrm{c}>3 \mathrm{M}), \mathrm{Fe}^{3+}$ and $\mathrm{H}^{+}$ions compete with each other, thus forming an impermeable layer (Antonijević et al., 1994).

Subsequently, the effect of initial concentration of sulfuric acid on copper recovery was studied in selected acid concentrate ranges $(10,15,25,30$, and 60$) \mathrm{g} / \mathrm{L}$. These tests were taken under the experimental conditions; silver: $150 \mathrm{ppm}, \mathrm{Py} / \mathrm{Ch}=3$, redox potential 470 $\mathrm{mV}$ and a temperature of $80^{\circ} \mathrm{C}$. The result of the one factor step-by-step experiment verifies that the initial concentration of acid does not have much of an effect on recovery. The considerable point in the obtained results is that a reduction of copper recovery occurred in the acid concentration of $60 \mathrm{~g} / \mathrm{L}$. As previously mentioned, this is probably caused by a high dissolution of pyrite in a highly concentrated acid solution and silver loss (see Figure 3).

\subsubsection{Effects of redox potential}

Figure 4 illustrates the effect of redox potential on the rate of copper dissolution. The results indicate that in potentials higher and lower than $470 \mathrm{mV}$ for chalcopyrite dissolution, copper recovery decreases. Considering all the performed activities, it seems that the reason for the reduced chalcopyrite dissolution in high potentials $(500 \mathrm{mV})$ is pyrite oxidation reducing the cathode surface and then elemental sulfur forms in higher potentials (over $530 \mathrm{mV}$ ) (Koleini et al., 2011).

Redox potential as an effective parameter in copper sulfide mineral leaching, especially chalcopyrite, is directly related to ferric to ferrous ion ratios and follows Nernst law. Research has proven that solution potential increases by increasing ferric ions to ferrous ratios in

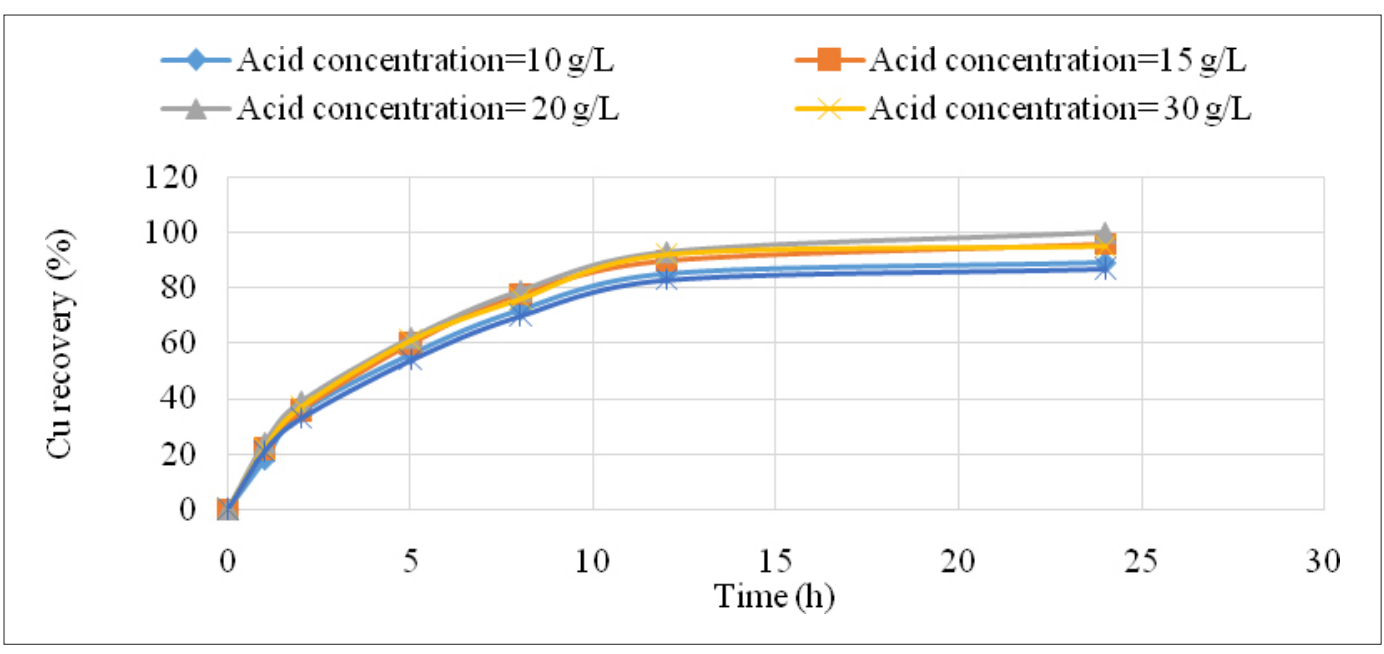

Figure 3: Chalcopyrite dissolution in acid concentrate, $\gamma=10,15,25,30$ and 6o g/L, silver ion; $\gamma\left(\mathrm{Ag}^{+}\right)=150 \mathrm{ppm}, \mathrm{Py} / \mathrm{Ch}=3$, redox potential, $\mathrm{E}_{\text {redox }}=470 \mathrm{mV}, \mathrm{T}=80^{\circ} \mathrm{C}$ 
accordance with Nernst law. Thus, chalcopyrite dissolution increases via increasing the ferric to ferrous ratio, but the potential increase is limited to some extent due to

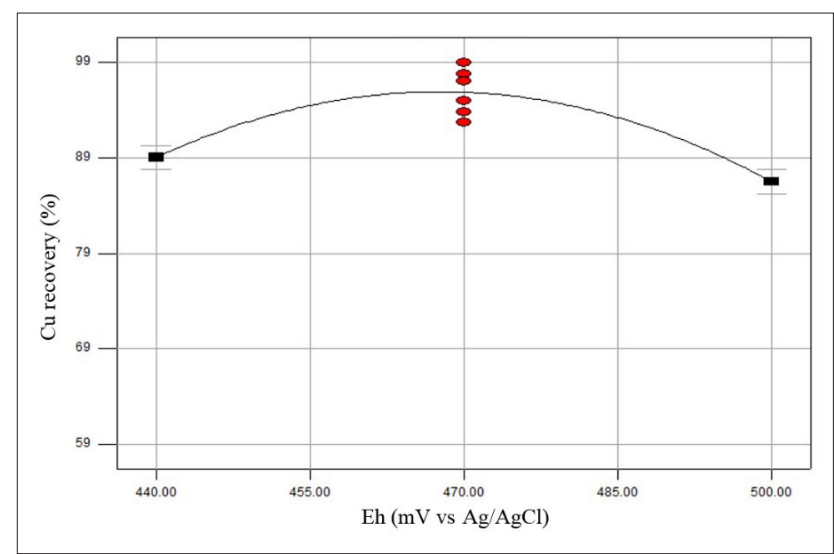

Figure 4: The effect of solution redox potential on the dissolution of copper the fact that the chalcopyrite dissolution rate does not increase after a certain ratio (Tshilombo et al., 2002). These statements are verified by Kametani and Aoki, claiming that in a potential strip (430 to $470 \mathrm{mV}$ vs Ag/ $\mathrm{AgCl}$ ), the rate of chalcopyrite dissolution achieved its maximum value (Kametani and Aoki, 1985). As cited before, a proper range of redox potential was obtained for chalcopyrite leaching in the presence of pyrite (400 to $420 \mathrm{mV}$ vs $\mathrm{Ag} / \mathrm{AgCl}$ ) (Koleini et al., 2011).

One factor experiments were performed in a redox potential range of 390 to $510 \mathrm{mV}$ vs $\mathrm{Ag} / \mathrm{AgCl}$ in the presence of silver ions (150 ppm), with an acid concentration of $25 \mathrm{~g} / \mathrm{L}, \mathrm{Py} / \mathrm{Ch}=3$ ratio and a temperature of $80^{\circ} \mathrm{C}$, indicating that in potentials higher than $500 \mathrm{mV}$ and lower than $430 \mathrm{mV}$, the dissolution process didn't take place perfectly (see Figure 5). It seems that chalcopyrite dissolution is reduced in potentials higher than $490 \mathrm{mV}$ wherein pyrite oxidation results in reduction at the cathodic level. Obviously, the best potential for chalcopyrite dissolution is $470 \mathrm{mV}$.

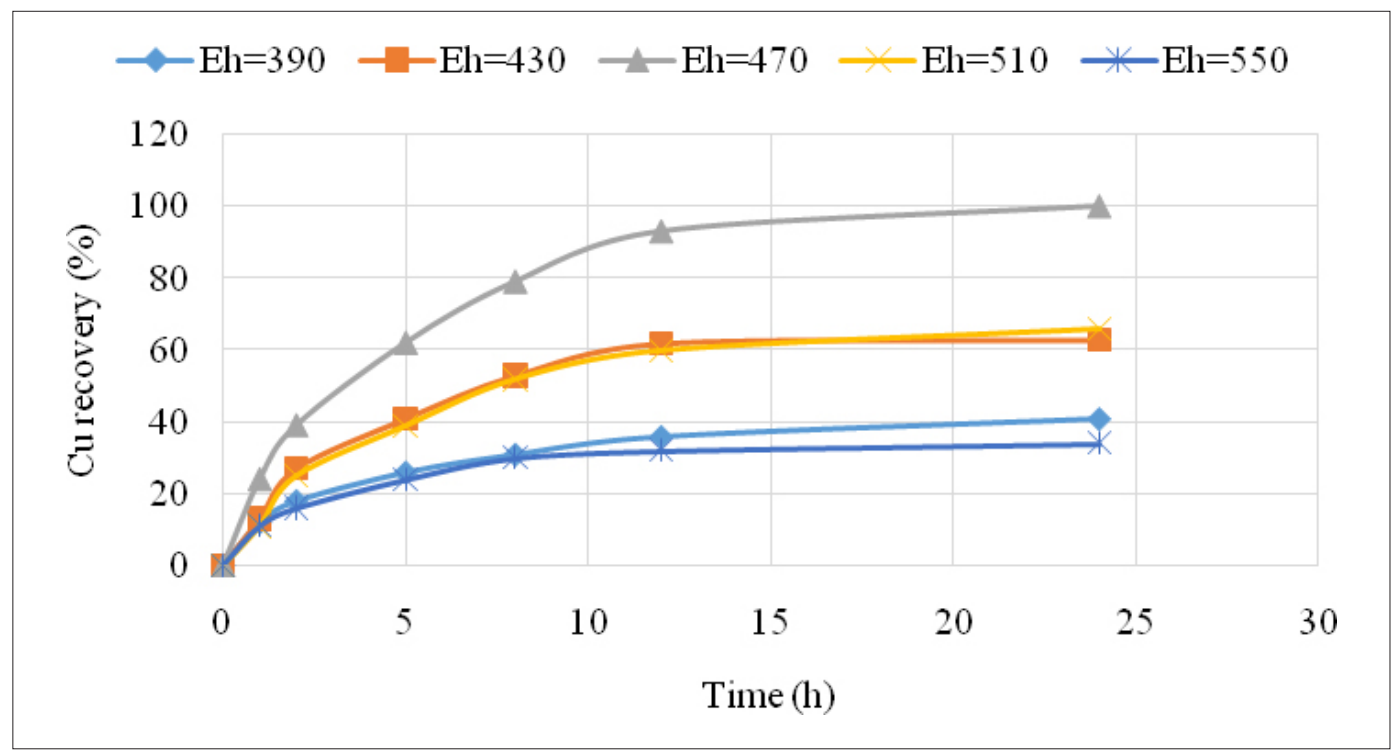

Figure 5: Chalcopyrite dissolution in redox potential, $\mathrm{E}_{\mathrm{redox}}=390,430,470$ and $510 \mathrm{mV}$, silver ion; $\gamma\left(\mathrm{Ag}^{+}\right)=150 \mathrm{ppm}$, $\mathrm{Py} / \mathrm{Ch}=3$, acid concentration, $\gamma=25 \mathrm{~g} / \mathrm{L}, \mathrm{T}=80^{\circ} \mathrm{C}$

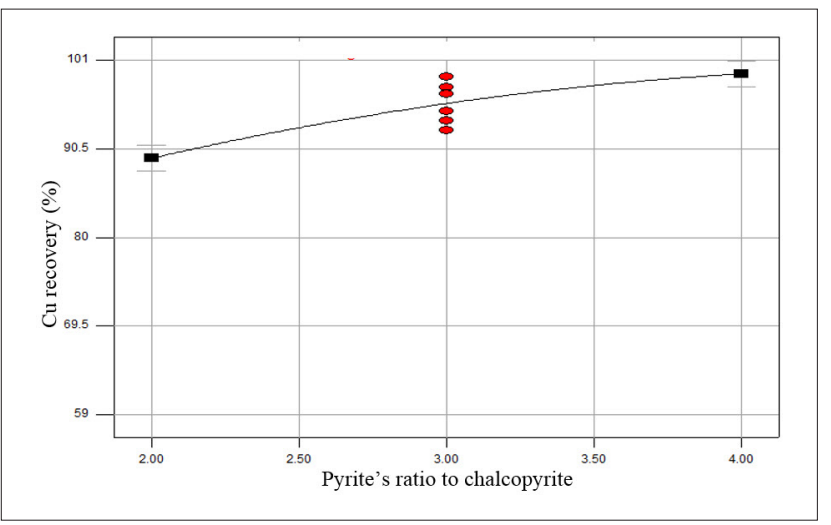

Figure 6: The effect of pyrite's ratio to chalcopyrite on the rate of copper dissolution
In these experiments, pyrite was used as a catalyst. To prevent pyrite dissolution, the potential must be maintained in the 420-460 $\mathrm{mV}$ range, wherein only chalcopyrite was dissolved and the other minerals could not be dissolved in the leach solution. This means that copper extraction occurred just in the limited potential range of 420-460 $\mathrm{mV}$. However, extracted iron ions in ferric form during the leaching process could produce jarosite, thus hindering chalcopyrite dissolution. Pyrite as a catalyst increases the solution cationic level and consequently reduces its ferric ions. It should be noted that three major factors can increase jarosite formation during the leaching process. These factors are temperature, ferric ions and $\mathrm{pH}$, all of which were controlled during our leaching tests. 


\subsubsection{Effect of pyrite's ratio to chalcopyrite}

Figure 6 shows the effect of the pyrite to chalcopyrite ratio on the rate of copper dissolution. As can be seen, by increasing the ratio, the rate of recovery also increases.

When two sulfide minerals contact each other electrically, an electron transfers from a mineral with a low rest

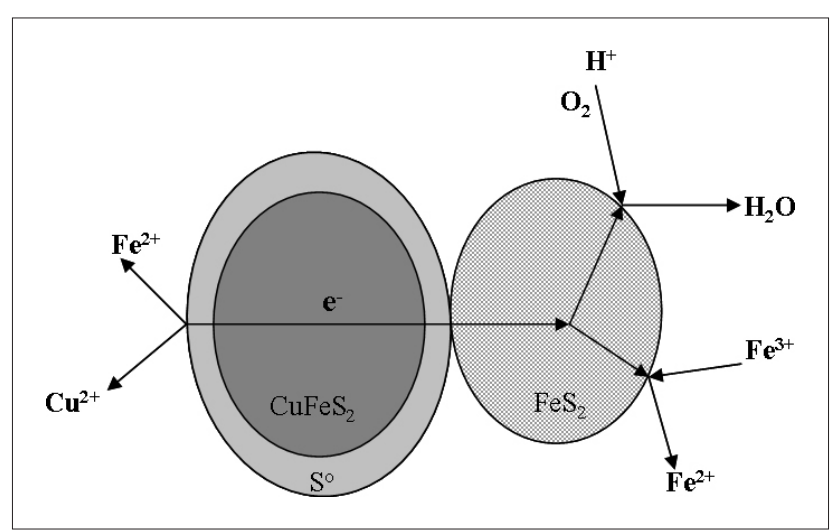

Figure 7: Diagram of cathodic and anodic reactions for a chalcopyrite/pyrite galvanic cell potential (anode) to a mineral with a high rest potential (cathode), forming a galvanic pile. The mentioned interactions between the sulfide minerals of chalcopyrite and pyrite can increase the presence of metal ions in the leach solution. Reactions $\mathbf{1}$ and $\mathbf{2}$ occur in the anode and cathode parts during the galvanox dissolution process, respectively. The galvanox mechanism of chalcopyrite dissolution in the presence of pyrite is shown in Figure 7.

$$
\begin{gathered}
\text { Cathodic reaction : } \mathrm{O}_{2}+4 \mathrm{H}^{+}+4 e^{-} \rightarrow 2 \mathrm{H}_{2} \mathrm{O} \\
\text { Anodic reaction }: \mathrm{MS} \rightarrow \mathrm{M}^{2+}+S+2 e^{-}
\end{gathered}
$$

It is cited before that due to the high rate of ferric ion reduction at the surface of pyrite compared to chalcopyrite, resulted from electrochemical studies, chalcopyrite leachability increases in the presence of pyrite. The leachability promotion is due to the fact that both chalcopyrite and pyrite oxidize in high potentials, so all parts on the surface of a cathode cannot act as a cathode and thus parts of its surface act as an anode. Under these conditions, the galvanic effect between two minerals reduces, resulting in chalcopyrite dissolution reduction

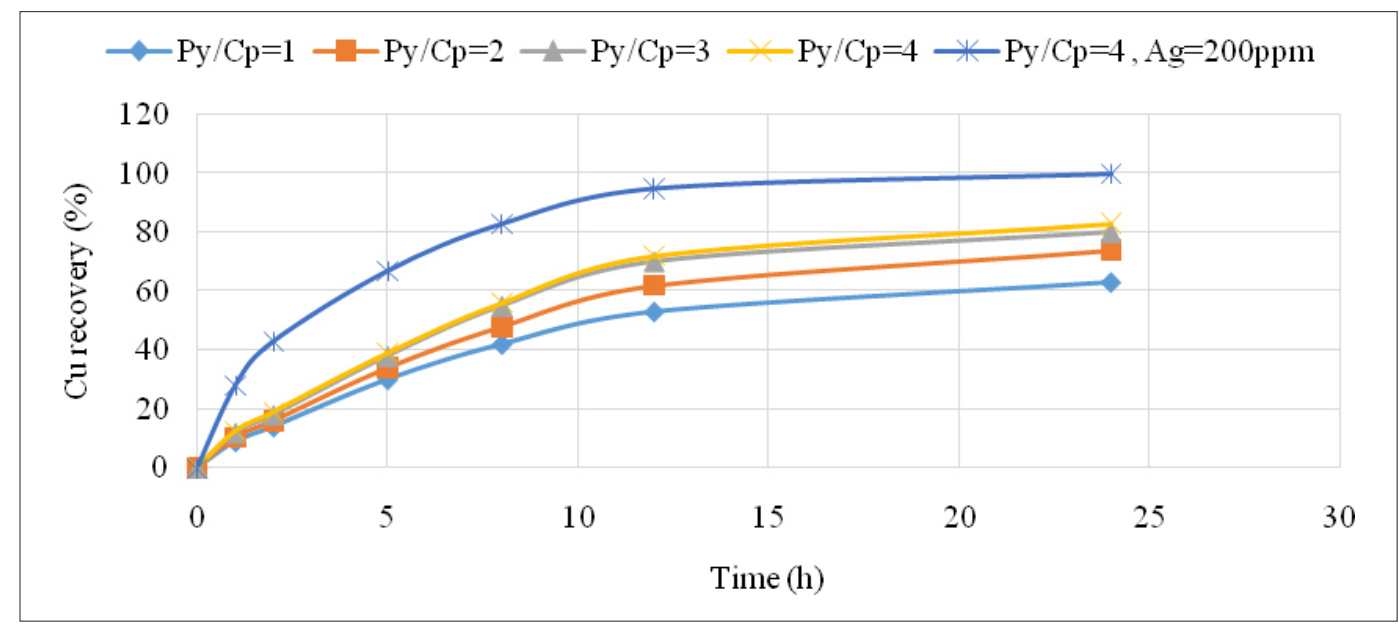

Figure 8: Chalcopyrite dissolution in redox potential, $E_{\text {redox }}=470 \mathrm{mV}, \mathrm{Py} / \mathrm{Ch}=1,2,3,4$ ratio and $\mathrm{Py} / \mathrm{Ch}=4$ silver ion; $\gamma\left(\mathrm{Ag}^{+}\right)=200 \mathrm{ppm}$ acid concentrate, $\gamma=25 \mathrm{~g} / \mathrm{L}, \mathrm{T}=8 \mathrm{o}^{\circ} \mathrm{C}$

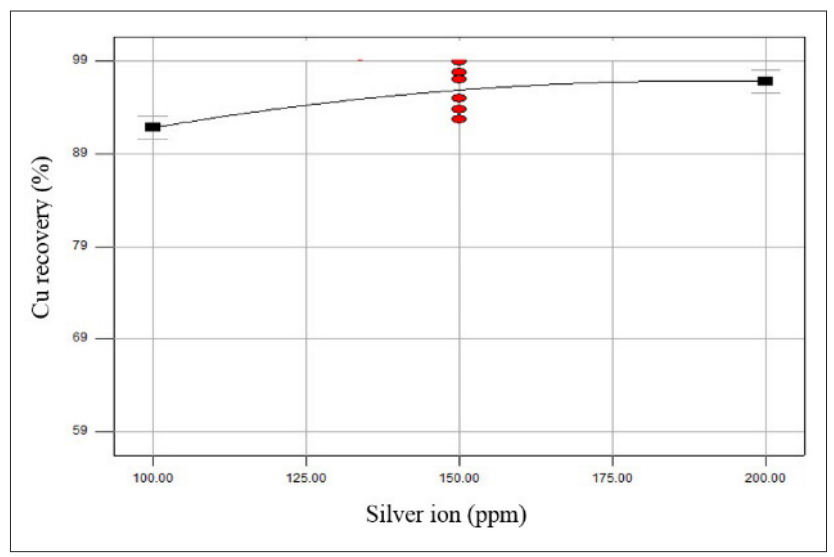

Figure 9: Effect of silver ions on copper dissolution rate
(Tshilombo et al., 2002). Increasing the pyrite to chalcopyrite ratio in the leaching solution can minimize pyrite particle size and consequently pyrite surface area will be increased, providing more cathodic surface and more ferric ion reduction. As described, copper recovery is increased with the ratio.

As mentioned before, a series of one factor experiments were conducted. The results of leaching tests conducted in the presence of pyrite and silver indicated that pyrite and silver ions could increase the copper dissolution rate (see Figure 8). Under the conditions, the rate of copper dissolution peaked at more than 90 percent after 10 hours. The improved dissolution rate can be attributed to the galvanic effect of pyrite and the catalytic effect 


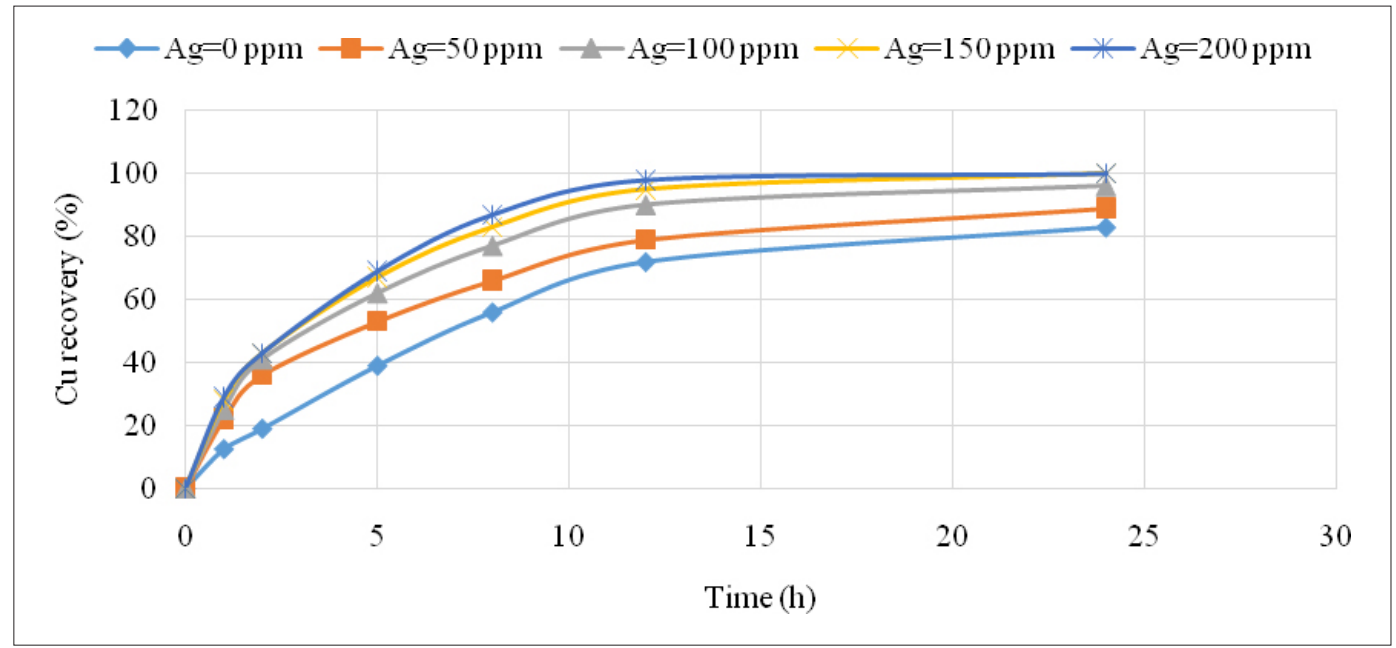

Figure 10: Chalcopyrite dissolution in redox potential, $E_{\mathrm{redox}}=470 \mathrm{mV}$, silver ion; $\gamma\left(\mathrm{Ag}^{+}\right)=0,50,100,150$ and $200 \mathrm{ppm}, \mathrm{Py} / \mathrm{Ch}=4$ ratio, acid concentrate, $\gamma=25 \mathrm{~g} / \mathrm{L}, \mathrm{T}=80^{\circ} \mathrm{C}$

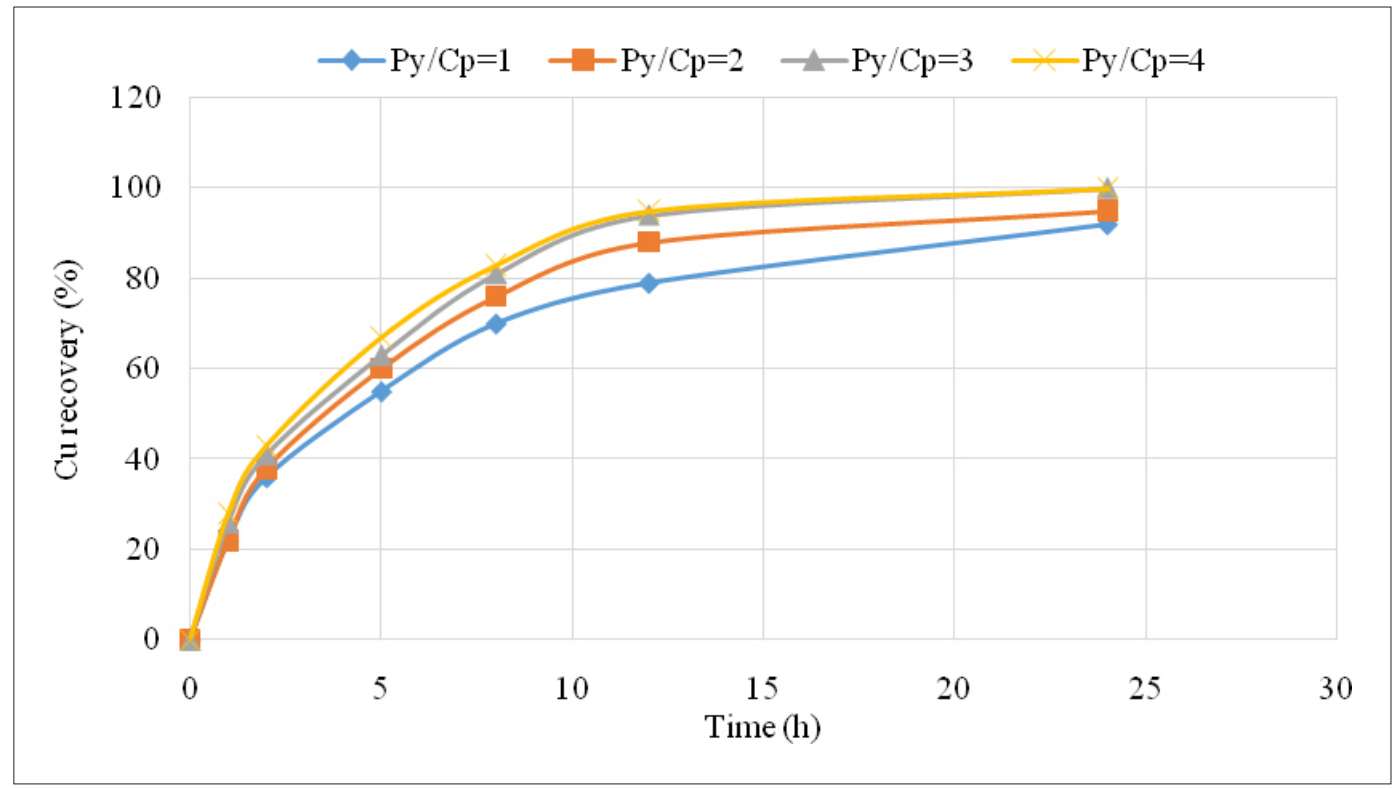

Figure 11: Chalcopyrite dissolution in redox potential, $\mathrm{E}_{\text {redox }}=47 \mathrm{o} \mathrm{VV}, \mathrm{Py} / \mathrm{Ch}=1,2,3,4$ ratio, silver ion; $\gamma\left(\mathrm{Ag}^{+}\right)=15 \mathrm{oppm}$ acid concentrate, $\gamma=25 \mathrm{~g} / \mathrm{L}, \mathrm{T}=80^{\circ} \mathrm{C}$

of silver in addition to its ability to eliminate the formed sulfonic layer during copper dissolution.

\subsubsection{Effect of silver ion}

Figure 9 presents the effect of silver ion on the copper dissolution rate. As it is clear in the figure, recovery increases by increasing silver ion consumption. In the absence of silver, pyrite shows cathodic behaviour. After the addition of silver, due to its adsorption on the chalcopyrite surface, the anodic units are formed on the chalcopyrite surface, increasing chalcopyrite dissolution.

Silver is a superseded chemical catalyser to improve chalcopyrite leaching via oxidation and reduction actions and reactions (Box and Hunter, 1961). When the silver ions are precipitated on the copper surface according to Equation 3, a silver sulfide is formed allowing for the diffusion of ferric and copper ions (Equations 4-6).

$$
\begin{gathered}
\mathrm{CuFeS}_{2}+4 \mathrm{Ag}^{+} \rightarrow \mathrm{Cu}^{2+}+\mathrm{Fe}^{2+}+2 \mathrm{Ag}_{2} \mathrm{~S} \\
n \mathrm{CuFeS} \mathrm{F}_{2}+4 \mathrm{Ag}^{+} \rightarrow\left(\mathrm{CuFeS}_{2}\right)_{n-1} \mathrm{Ag}_{4} \mathrm{~S}_{2}+\mathrm{Cu}^{2+}+\mathrm{Fe}^{2+} \\
\mathrm{Ag}_{2} \mathrm{~S}+2 \mathrm{Fe}^{3+} \rightarrow 2 \mathrm{Ag}^{+}+2 \mathrm{Fe}^{2+}+\mathrm{S}^{0} \\
\mathrm{Ag}_{2} \mathrm{~S}+\mathrm{O}_{2}+4 \mathrm{H}^{+} \rightarrow 4 \mathrm{Ag}^{+}+2 \mathrm{~S}^{0}+2 \mathrm{H}_{2} \mathrm{O}
\end{gathered}
$$

Cordoba et al., (2008) demonstrated that with the addition of a silver activator, the activation energy was satisfiability reduced. In fact, the rate of energy was decreased from $130.7 \mathrm{~kJ} / \mathrm{mol}$ before the addition of silver to $29.3 \mathrm{~kJ} / \mathrm{mol}$ after the addition of silver (Córdoba et al., 2008). To get a better evaluation of the silver ion 


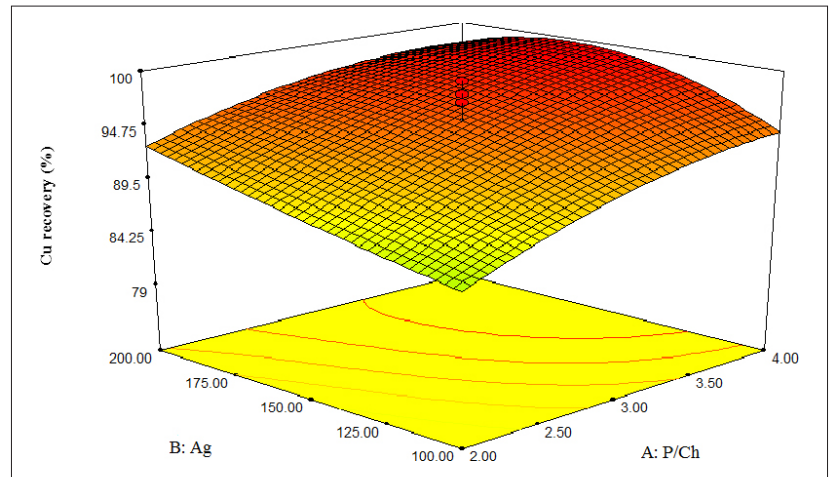

Figure 12: Interaction effect of pyrite ration to chalcopyrite and the amount of consuming silver ions on recovery

amount, a series of tests with a one variable factor design were carried out with various amounts of silver concentration $(0,50,100,150$ and $200 \mathrm{ppm})$. The obtained results prove the copper recovery increased to more than $95 \%$ in the presence of $150 \mathrm{ppm}$ silver ions after less than 10 hours (see Figure 10).

To determine the optimum amount of silver ion and the effect of the simultaneous use of pyrite and silver, more leaching tests were performed in the presence of $150 \mathrm{ppm}$ silver ion and pyrite to chalcopyrite ratios 1,2 , 3 and 4 . The results indicate that copper recovery can increase to $95 \%$ after 10 hours with $\mathrm{Py} / \mathrm{Ch}=3$ and 150 ppm silver (see Figure 11). Also, the interaction of pyrite to chalcopyrite ratio and silver ions concentration on copper dissolution are depicted in Figure 12.

\subsection{Interaction of factors}

Considering the effect of all factors in dissolution, it can be concluded that all the factors have an important role in the dissolution process as the obtained results confirm (see Figure 13). An increase in the pyrite to chalcopyrite ratio and the silver concentration additive, as well as the reduction of redox potential and primitive acid concentration result in the promoted chalcopyrite solution. Finally, the results uncovered that all the fac-

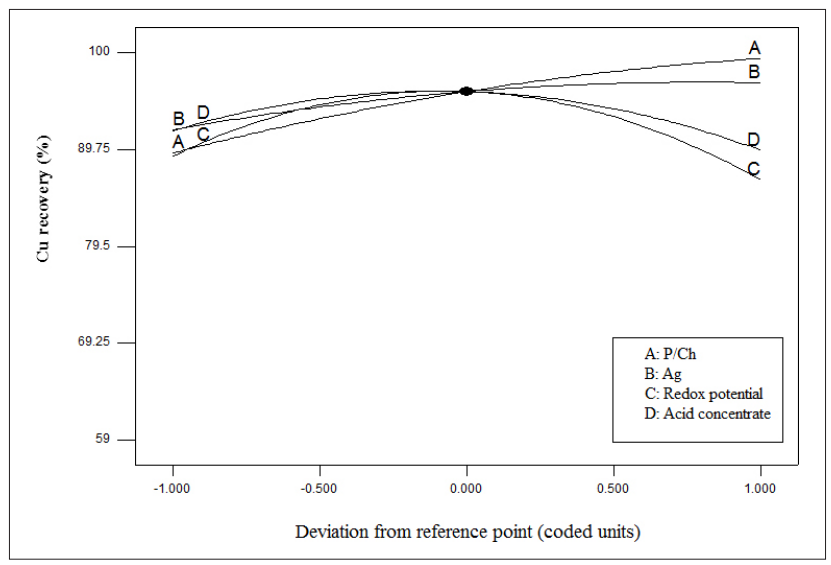

Figure 13: Interaction of all factors on the dissolution rate of copper tors affect each other whereas maximum recovery was attained in the optimal number of factors.

\section{Conclusions}

In this study, Response Surface Methodology (RSM) and Central Composite Design (CCD) were used to study the interaction between factors such as the amount of pyrite, silver ions, redox potential and the initial concentration of acid on the dissolution of chalcopyrite concentrate as well as the modelling and optimization of the four selected parameters on leaching efficiency.

Previous research proved that the chalcopyrite oxidation process formed sulfur layers on the chalcopyrite surface with high electric resistance. The passive layer restricted electron transfers from chalcopyrite to pyrite, hindering galvanic function between them. The amount of pyrite has a significant effect on chalcopyrite leaching through galvanic cell formation between chalcopyrite and pyrite. It was verified that in the presence of silver ions, pyrite effectiveness was improved and also the dissolution rate increased considerably. The results also confirmed that although the rate of silver reaction with sulfuric layer was very low, the resistance of this layer considerably decreased. Decreasing electric resistance of the sulfur layer with the addition of silver ions, electrons easily transferred from chalcopyrite to pyrite with a satisfying rate, thus improving the dissolution process of chalcopyrite concentrate. In addition, the variation of electric resistance of the sulfur layer in different concentrations of silver ion was studied. The results proved that electric resistance of the sulfur layer was decreased by increasing the silver ion concentration. Considering the interaction between pyrite and silver ions, it was found that pyrite performance was improved in the presence of silver ions and copper recovery increased satisfiability. Other parameters such as: temperature, redox potential and initial concentration of the acid had a significant effect on chalcopyrite dissolution. Finally, the results revealed that the optimal conditions of chalcopyrite leaching in the presence of pyrite and silver ions can be as follows; a stirring speed of $1000 \mathrm{rpm}$, pyrite to chalcopyrite ratio $=3$, silver ion concentration of $150 \mathrm{ppm}$, redox potential $=470 \mathrm{mV}$, a temperature of $80^{\circ} \mathrm{C}$ and an initial acid concentration of $25 \mathrm{~g} / \mathrm{L}$. In the obtained optimum conditions, the copper recovery could be increased to more than $95 \%$ after less than 10 hours.

\section{References}

Antonijević, M., Bogdanović, G. (2004): Investigation of the Leaching of Chalcopyritic Ore in Acidic Solutions. Hydrometallurgy, 73 (3-4), 245-256.

Antonijević, M., Janković, Z., Dimitrijević, M. (1994): Investigation of the Kinetics of Chalcopyrite Oxidation by Potassium Dichromate. Hydrometallurgy, 35 (2), 187-201. 
Arce, E.M., González, I. (2002): A Comparative Study of Electrochemical Behavior of Chalcopyrite, Chalcocite and Bornite in Sulfuric Acid Solution. International Journal of Mineral Processing, 67 (1-4), 17-28.

Aydogan, S., Ucar, G., Canbazoglu, M. (2006): Dissolution Kinetics of Chalcopyrite in Acidic Potassium Dichromate Solution. Hydrometallurgy, 81 (1), 45-51.

Berry, V., Murr, L., Hiskey, J.B. (1978): Galvanic Interaction between Chalcopyrite and Pyrite During Bacterial Leaching of Low-Grade Waste. Hydrometallurgy, 3 (4), 309-326.

Box, G.E., Hunter, J.S. (1961): The 2 K-P Fractional Factorial Designs. Technometrics, 3 (3), 311-351.

Buckley, A.N., Woods, R. (1984): An X-Ray Photoelectron Spectroscopic Study of the Oxidation of Chalcopyrite. Australian Journal of Chemistry, 37 (12), 2403-2413.

Córdoba, E., Muñoz, J., Blázquez, M., González, F., Ballester, A. (2008): Leaching of Chalcopyrite with Ferric Ion. Part I: General Aspects. Hydrometallurgy, 93 (3-4), 81-87.

Córdoba, E., Muñoz, J., Blázquez, M., González, F., Ballester, A. (2009a): Comparative Kinetic Study of the Silver-Catalyzed Chalcopyrite Leaching at 35 and $68 \mathrm{C}$. International Journal of Mineral Processing, 92 (3-4), 137-143.

Córdoba, E., Muñoz, J., Blázquez, M., González, F., Ballester, A. (2009b): Passivation of Chalcopyrite During Its Chemical Leaching with Ferric Ion at 68 C. Minerals Engineering, 22 (3), 229-235.

Dixon, D.G., Baxter, K., Sylwestrzak, L. (2007): Galvanox ${ }^{\mathrm{TM}}$ Treatment of Copper Concentrates. Alta Copper, 11.

Dreisinger, D., Abed, N. (2002): A Fundamental Study of the Reductive Leaching of Chalcopyrite Using Metallic Iron Part I: Kinetic Analysis. Hydrometallurgy, 66 (1-3), 37-57.

Dutrizac, J. (1981): The Dissolution of Chalcopyrite in Ferric Sulfate and Ferric Chloride Media. Metallurgical Transactions B, 12 (2), 371-378.

Ferreira, S.L.C., Bruns, R.E., da Silva, E.G.P., Dos Santos, W.N.L., Quintella, C.M., David, J.M., de Andrade, J.B., Breitkreitz, M.C., Jardim, I.C.S.F., Neto, B.B. (2007): Statistical Designs and Response Surface Techniques for the Optimization of Chromatographic Systems. Journal of chromatography A, 1158 (1-2), 2-14.

Hackl, R., Dreisinger, D., Peters, E., King, J. (1995): Passivation of Chalcopyrite During Oxidative Leaching in Sulfate Media. Hydrometallurgy, 39 (1), 25-48.

Harmer, S.L., Thomas, J.E., Fornasiero, D., Gerson, A.R. (2006): The Evolution of Surface Layers Formed During Chalcopyrite Leaching. Geochimica et Cosmochimica Acta, 70 (17), 4392-4402.

Hiroyoshi, N., Arai, M., Miki, H., Tsunekawa, M., Hirajima, T. (2002): A New Reaction Model for the Catalytic Effect of Silver Ions on Chalcopyrite Leaching in Sulfuric Acid Solutions. Hydrometallurgy, 63 (3), 257-267.

Isar, J., Agarwal, L., Saran, S., Saxena, R.K. (2006): A Statistical Method for Enhancing the Production of Succinic Acid from Escherichia Coli under Anaerobic Conditions. Bioresource technology, 97 (13), 1443-1448.

Kametani, H., Aoki, A. (1985): Effect of Suspension Potential on the Oxidation Rate of Copper Concentrate in a Sulfuric Acid Solution. Metallurgical Transactions B, 16 (4), 695-705.
Klauber, C., Parker, A., van Bronswijk, W., Watling, H. (2001): Sulphur Speciation of Leached Chalcopyrite Surfaces as Determined by X-Ray Photoelectron Spectroscopy. International Journal of Mineral Processing, 62 (1-4), 65-94.

Koleini, S.J., Aghazadeh, V., Sandström, Å. (2011): Acidic Sulphate Leaching of Chalcopyrite Concentrates in Presence of Pyrite. Minerals Engineering, 24 (5), 381-386.

Koleini, S.J., Jafarian, M., Abdollahy, M., Aghazadeh, V. (2010): Galvanic Leaching of Chalcopyrite in Atmospheric Pressure and Sulfate Media: Kinetic and Surface Studies. Industrial \& Engineering Chemistry Research, 49 (13), 5997-6002.

Körbahti, B.K., Rauf, M. (2008): Response Surface Methodology (Rsm) Analysis of Photoinduced Decoloration of Toludine Blue. Chemical Engineering Journal, 136 (1), 25-30.

Li, J., Kawashima, N., Kaplun, K., Absolon, V., Gerson, A. (2010): Chalcopyrite Leaching: The Rate Controlling Factors. Geochimica et Cosmochimica Acta, 74 (10), 2881-2893.

Linge, H. (1977): Reactivity Comparison of Australian Chalcopyrite Concentrates in Acidified Ferric Solution. Hydrometallurgy, 2 (3), 219-233.

Liu, H.-L., Chiou, Y.-R. (2005): Optimal Decolorization Efficiency of Reactive Red 239 by Uv/Tio2 Photocatalytic Process Coupled with Response Surface Methodology. Chemical Engineering Journal, 112 (1-3), 173-179.

Nazari, G., Dixon, D., Dreisinger, D. (2011): Enhancing the Kinetics of Chalcopyrite Leaching in the Galvanox ${ }^{\mathrm{TM}}$ Process. Hydrometallurgy, 105 (3-4), 251-258.

Parker, A., Paul, R., Power, G. (1981): Electrochemistry of the Oxidative Leaching of Copper from Chalcopyrite. Journal of Electroanalytical Chemistry and Interfacial Electrochemistry, 118, 305-316.

Salehi, S., Noaparast, M., Shafaei, S.Z. (2016): Response Surface Methodology (Rsm) for Optimization of Chalcopyrite Concentrate Leaching with Silver-Coated Pyrite. Physicochemical Problems of Mineral Processing, 52.

Stott, M., Watling, H., Franzmann, P., Sutton, D. (2000): The Role of Iron-Hydroxy Precipitates in the Passivation of Chalcopyrite During Bioleaching. Minerals Engineering, 13 (10-11), 1117-1127.

Tshilombo, A., Petersen, J., Dixon, D. (2002): The Influence of Applied Potentials and Temperature on the Electrochemical Response of Chalcopyrite During Bacterial Leaching. Minerals Engineering, 15 (11), 809-813.

Viramontes-Gamboa, G., Peña-Gomar, M.M., Dixon, D.G. (2010): Electrochemical Hysteresis and Bistability in Chalcopyrite Passivation. Hydrometallurgy, 105 (1-2), 140-147.

Xian, Y., Wen, S., Deng, J., Liu, J., Nie, Q. (2012): Leaching Chalcopyrite with Sodium Chlorate in Hydrochloric Acid Solution. Canadian Metallurgical Quarterly, 51 (2), $133-140$.

Yin, Q., Kelsall, G., Vaughan, D., England, K. (1995): Atmospheric and Electrochemical Oxidation of the Surface of Chalcopyrite (Cufes 2). Geochimica et Cosmochimica Acta, 59 (6), 1091-1100. 
Yuehua, H., Guanzhou, Q., Jun, W., Dianzuo, W. (2002): The Effect of Silver-Bearing Catalysts on Bioleaching of Chalcopyrite. Hydrometallurgy, 64 (2), 81-88.

Zinatizadeh, A., Mohamed, A., Abdullah, A., Mashitah, M., Isa, M.H., Najafpour, G. (2006): Process Modeling and
Analysis of Palm Oil Mill Effluent Treatment in an upFlow Anaerobic Sludge Fixed Film Bioreactor Using Response Surface Methodology (Rsm). Water Research, 40 (17), 3193-3208.

\section{SAŽETAK}

\section{Optimizacija galvanskoga izluživanja halkopirita uporabom pirita i srebra kao katalizatora te uporabom metode odzivne površine}

U ovome istraživanju modelirano je otapanje koncentriranoga halkopirita te je proces optimiziran uporabom metode odzivne površine. Također su istražene efektivne varijable tijekom toga procesa, i to količina pirita, iona srebra, redokspotencijal i početna koncentracija kiseline. Metodom središnjega kompozitnog dizajna određena je matrica za predviđanje najboljega odnosa tih varijabli. Nakon toga je pokazano kako nazočnost iona srebra povećava efikasnost pirita, što je rezultiralo znatno većom topivošću halkopirita. Kvadratičnim programiranjem određene su sljedeće vrijednosti kao optimalne: brzina rotacije od 1000 okretaja u minuti, zatim maseni odnos pirita i halkopirita $3: 1$, koncentracija iona srebra $150 \mathrm{ppm}$, potencijal topivosti od $470 \mathrm{mV}$ na $800{ }^{\circ} \mathrm{C}$ te početna koncentracija kiselina $25 \mathrm{~g} / \mathrm{L}$. Time je postignuto maksimalno izluživanje bakra (uspješnosti veće od 95\%) za vrijeme kraće od 10 sati.

\section{Ključne riječi:}

halkopirit, otapanje, efekt galvanizacije, metoda odzivne površine

\section{Authors contribution}

Sajjad Chehreghani, Assistant Professor of Mining Engineering, and Amir Zeynali, MSc graduated, collaborated in the literature review, data collection and analysis procedure for this manuscript. Mojtaba Yari, Behzad Nemati Akhgar and Hojjat Hosseinzadeh Gharehgheshlagh, Assistant Professors of Mining Engineering, collaborated on the analysis procedure, writing and managing the whole process of this manuscript. Mahsa Pishravian is BSc graduate who participated in data collection. 